Scientific Review - Engineering and Environmental Sciences (2020), 29 (2), 184-195

Sci. Rev. Eng. Env. Sci. (2020), 29 (2)

Przegląd Naukowy - Inżynieria i Kształtowanie Środowiska (2020), 29 (2), 184-195

Prz. Nauk. Inż. Kszt. Środ. (2020), 29 (2)

http://iks.pn.sggw.pl

DOI 10.22630/PNIKS.2020.29.2.16

Ibtihaj S. ABDULFATTAH ${ }^{1}$, Jasim M. RAJAB ${ }^{2,3}$, Ali M. Al-SALIHI ${ }^{2}$, Aha SULIMAN ${ }^{3}$, Hwee San LIM ${ }^{4}$

${ }^{1}$ Mustansiriyah University Presidency, Division of Human resources

${ }^{2}$ Mustansiriyah University, College of Science

${ }^{3}$ University of Al-Hamdaniya, Laser and Photonics Research Center

${ }^{4}$ Universiti Sains Malaysia, School of Physics

\title{
Observed vertical distribution of tropospheric carbon monoxide during 2012 over Iraq
}

Key words: AIRS, remote sensing, pollution, carbone monoxide, Iraq

\section{Introduction}

Both as an air pollutant and as a significant in atmospheric chemistry, the $\mathrm{CO}$ is an efficient research topic entails accurate representation of the magnitude and location of $\mathrm{CO}$ surface emissions (Fortems-Cheiney et al., 2011). The CO is regulated as the Environmental Protection Agency (EPA) specification pollutant due to of its lineal adverse effectiveness on human health. It emitted by incomplete combustion of hydrocarbons and industrial operations to the atmosphere such as iron smelting (Al-Bayati \& Al-Salihi, 2019). It importantly affects the $\mathrm{OH}$ budget, and thus secondar- ily impacts the ozone $\left(\mathrm{O}_{3}\right)$ and methane $\left(\mathrm{CH}_{4}\right)$ concentrations. The $\mathrm{CO}$ affecting air quality and climate, and acts as a serious indirect greenhouse gases (GHGs) because of it does not absorb terrestrial thermal infrared (IR) from the Earth. These is due to the $\mathrm{CO}$ distinctive by indirect radiative forcing raises and effect the troposphere $\mathrm{CH}_{4}$ and $\mathrm{O}_{3}$ measurements through chemical reactions with other atmospheric constituents (Rajab, Jafri, Lim \& Abdullah, 2011; Herron-Thorpe et al., 2012; Faten, 2018). The two largest surface sources of $\mathrm{CO}$ are the fossil fuel and combustion of biomass. In general, agreed the biomass burning accounts almost one quarter of $\mathrm{CO}$ emission to the atmosphere (Pétron et al., 2004). Carbone monoxide molecular have a global-average lifetime of about two months and it weight is close to that 
of air. Unpredictability in the $\mathrm{CO}$ budget are still rightly large due to distress in quantify the variability of $\mathrm{CO}$ sources and sinks, because of the lack of emissions statistics and quantification used to derive emissions inventories (Drori et al., 2012).

Although the aircraft-mounted and ground-based devices are able to make precise observations of $\mathrm{CO}$ measurements in the troposphere, they are not able to provide large-scale global or regional coverage. Only the space observations allow such measurements (in the absence of cloud) to be made over a rationally short time period. Over the past decade IMG (Interferometer Monitor for Greenhouse Gases) (Kobayashi et al., 1999), MOPITT (Measurements of Pollution in the Troposphere) (Deeter et al., 2010), TES (Tropospheric Emission Spectrometer) (Bowman et al., 2006; Luo et al., 2007) and AIRS (Automated Import Reference System) (McMillan et al., 2003). Sensors have all successfully implemented measurements in the $4.7 \mu \mathrm{m}$ spectral band to increase the vertical information content of profiles and also global coverage as well as cost so much money and arduous efforts (Illingworth et al., 2011).

The satellite remote sensing provide good global coverage and quantitatively data with crucial temporal or spatial resolution, and boost the researcher ability to understand the impact of human activities on the chemical composition of the atmosphere and climate change. Also, the free download satellite information provided by AIRS website. Therefore, the scientists have explored its use in studying fire emission and biomass burning. Parameters deduced from satellite data include aerosol index, fire counts, biomass density, and fire counts. Using these parameters from satellite data, the $\mathrm{CO}$ emission has been indirectly estimated from vegetation fires (Rajab, Jafri, Lim \& Abdullah, 2012). The Aqua satellite put to space aboard Aqua satellite by the NASA on 4 May 2002 provide vertical profiles of the atmosphere with a nadir $45 \mathrm{~km}$ field-of-regard (FOR) across a $1650 \mathrm{~km}$ swath. The AIRS have wide spectral coverage (3.7-16 $\mu \mathrm{m}$ with 2,378 channels) comprises spectral features of $\mathrm{O}_{3}, \mathrm{CH}_{4}, \mathrm{CO}$, and $\mathrm{CO}_{2}$. The AIRS observe the $\mathrm{CO}$ total column by 36 channels with vertical encasement 1,000-1 mb. The troposphere CO multitude is restore in the 4.58-4.50 $\mu \mathrm{m}\left(2,180-2,220 \mathrm{~cm}^{-1}\right)$ area from AIRS observed radiances of IR spectrum (Chahine et al., 2006; Rajab, Hassan, Kadhum, Al-Salihi \& Hwee, 2020).

In this study we present the AIRS vertical (seven levels CO) profile observations of troposphere $\mathrm{CO}$ obtained during the year 2012. The restored AIRS monthly L3 product V5 measurements were utilized. We show the temporal and vertical distribution of troposphere $\mathrm{CO}$ across Iraq for five locations; Baghdad, Basra Mosul, Al Fakka, and Maysan, in study period. The seven layers monthly CO MVR was produced using kriging interpolation technique to analyses its allocation over study area during 2012. With AIRS observations, spatial and temporal differences of $\mathrm{CO}$ emission able are examined directly and separately from other approaches over various areas. 


\section{Material and methods}

\section{Study area and climate features}

Iraq, located in the western part of Asia and mainly occupies the Mesopotamian Plain, located, between $39^{\circ}$ and $49^{\circ} \mathrm{E}$ longitudes (a small area lies west of $39^{\circ}$ ) and $29^{\circ}$ and $38^{\circ} \mathrm{N}$ latitudes. At the north, Iraq borders by Turkey, Kuwait and Saudi Arabia at south, Syria at northwest, Iran at east, and Jordan at southwest. Iraq country involves of 437,072 $\mathrm{km}^{2}$ by 18 states; it is the $58^{\text {th }}$ biggest country in the world (Faten, 2018; Al-Salihi, Rajab \& Salih, 2019). b) Southern Region bounded by the longitudes of 44.45 and $48.50^{\circ} \mathrm{E}$ and latitudes 30.11 and $32.30^{\circ} \mathrm{N}$.

c) Western Region bounded by longitudes 43.19 and $44.32^{\circ} \mathrm{E}$ and latitudes 30.30 and $33.15^{\circ} \mathrm{N}$.

d) Central Region bounded by longitudes of 45.20 and $45.19^{\circ} \mathrm{E}$, and latitudes 31.81 and $34.18^{\circ} \mathrm{N}$.

\section{Acquisition and specification}

The data used in this study was acquired from AIRS Level-3 (L3) ascending data (NASA Earthdata, 2019). Generally, ascending granules L3 data

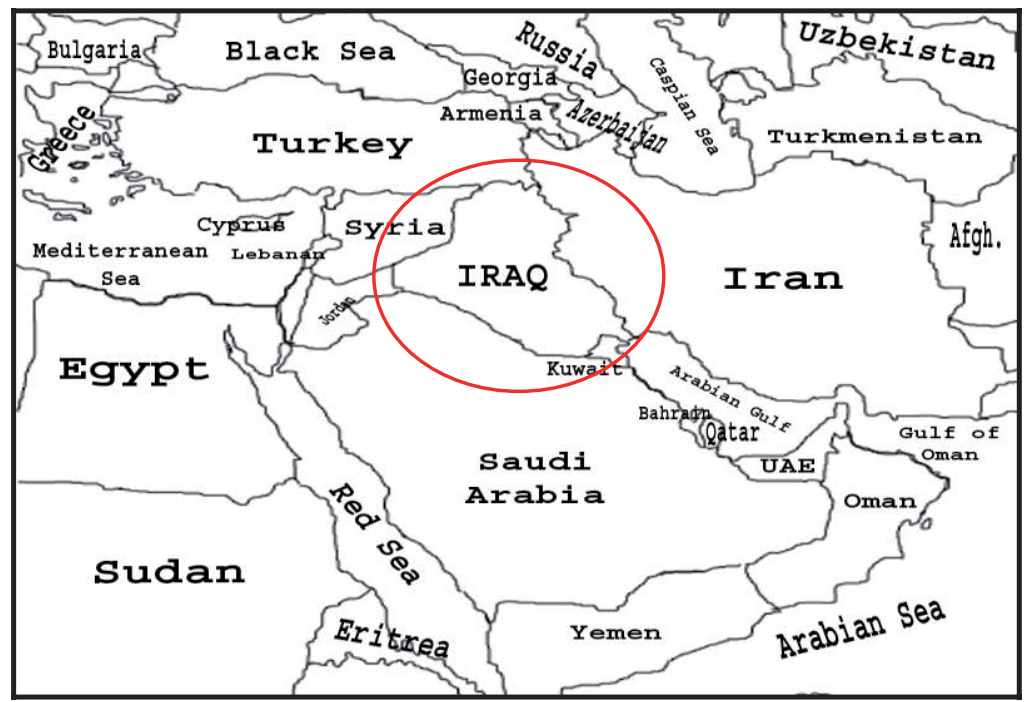

FIGURE 1. The geographical attribute of study area (Rajab, Ahmed, \& Moussa, 2013)

The Iraqi Meteorological and Seismology Organization (IMSO) divide Iraq into four regions according to geological, meteorological and hydrological characteristics as follows:

a) Northern Region bounded by longitudes 43.09 and $43.50^{\circ} \mathrm{E}$, and latitudes 34.11 and $36.19^{\circ} \mathrm{N}$. downloaded for 12 months (January-December) to get the required output. The data are covering Iraq as a grid of 132 points extends from $28.5-49.5^{\circ} \mathrm{N}$ latitudes and $38.5-49.5^{\circ} \mathrm{E}$ longitudes with a uniform grid interval of $1^{\circ}$ in longitude and $1^{\circ}$ in latitude. In previous papers, we discussed the distribution of $\mathrm{CO}$ 
for different periods (2003-2016) over Iraq using spatial, temporal, and trends (Rajab et al., 2013; Salih, Al-Salihi \& Rajab, 2018; Al-Salihi et al., 2019). To preferable exam the vertical distribution of CO VMR above Iraq for the study period the cross section, time-pressure of $\mathrm{CO}$, mole fraction in air (daytime/ /ascending) monthly $1^{\circ}$ (AIRS AIRX3STM v006) over January-December 2012, Region 49E, 28N, 38E, and 49N map obtained from the NASA-operated GIOVANNI website. Seven atmospheric layers $\mathrm{CO}$ data used in this work with height and pressures are summarized in Table 1, for vertical analysis. In addition, surface $\mathrm{CO}$ values for time series distribution and comparison. The difficulty in obtaining the monthly ground $\mathrm{CO}$ data, due to Iraq circumstances, only Baghdad station $\mathrm{CO}$ data were collected from Iraqi Meteorological Office for compression and regression analysis with AIRS data during the period 2012. The simple linear regression is utilized to model the relationship between two singles, response and exploratory, variables $y$ and $x$. The SigmaPlot software were used for this model between the ground and AIRS monthly CO values over Baghdad station; the model is
$y_{i}=\hat{A}_{0}+\hat{A}_{1} x_{i}+\varepsilon_{i}$

where:

$\left(x_{i}, y_{i}\right), i=1, \ldots, n-$ response and exploratory variables sample values,

$\hat{A}_{0}-$ intercept parameter,

$\hat{A}_{1}$ - slope parameter,

$\varepsilon_{i}$ - random disturbance terms (Landau \& Everitt, 2004).

In order to evaluate and investigate the seasonal change in troposphere $\mathrm{CO}$ emission, two steps were used to analyze the data. The first step is monthly basis file data, including the identical location and time in a HDF (hierarchical data format) format from AIRS website, and set out in table using MS Excel. In the second step the five dispersed locations were selected across Iraq (Baghdad, Mosul, Basra, Al Fakka and Maysan), as summarized in Table 1. Two graphs between $\mathrm{CO}$ with altitude, and troposphere $\mathrm{CO}$ with months for 2012, respectively, were designed to detect the seasonal change in $\mathrm{CO}$ values for the study period.

\section{Results and discussion}

The first analysis for the data showed that there is significant increase of maximum values of the troposphere $\mathrm{CO}$ in

TABLE 1. Height and pressure of the layers (left) and stations GMD (right)

\begin{tabular}{|c|c|c|c|c|c|}
\hline Layer & $\begin{array}{c}\text { Height } \\
{[\mathrm{m}]}\end{array}$ & $\begin{array}{c}\text { Pressure } \\
{[\mathrm{hPa}]}\end{array}$ & \multirow{3}{*}{ Station } & \multirow{3}{*}{ Longitude } & \multirow{3}{*}{ Latitude } \\
\hline 0 & 13500 & 155.625 & & & \\
\hline 1 & 11000 & 253.5 & & & \\
\hline 2 & 8500 & 351 & Baghdad & $44.36 \mathrm{E}$ & $33.31 \mathrm{~N}$ \\
\hline 3 & 5820 & 505.25 & Mosul & $43.16 \mathrm{E}$ & $36.35 \mathrm{~N}$ \\
\hline 4 & 3100 & 706 & Basra & $47.78 \mathrm{E}$ & $30.50 \mathrm{~N}$ \\
\hline 5 & 1450 & 850 & Al Fakka & $47.30 \mathrm{E}$ & $32.10 \mathrm{~N}$ \\
\hline 6 & 750 & 930 & Maysan & $47.10 \mathrm{E}$ & $31.50 \mathrm{~N}$ \\
\hline
\end{tabular}


March over all five locations. Figure 2 illustrates monthly troposphere CO from January to December 2012 for five locations; Baghdad, Basrah, Maysan, Al Fak$\mathrm{ka}$, and Mosul. The standard deviation of monthly troposphere CO was (107.15 $\pm 18.75 \mathrm{ppbv})$ for the whole period. Elevation in troposphere $\mathrm{CO}$ observed along study period over the manufacturing and crowded urban zones, i.e. Baghdad, Mosul and Basra. The CO exposure differences seasonal alterations depend on whether circumstance and topography. The seasonal variations undulate between winters and summer seasons. A more certain inspections illustrate a spatial pattern subtle differences in the $\mathrm{CO}$ values for each season. A minimum value of the $\mathrm{CO}$ occurs in October. The seasonal differences are observable, but none are as declared during the study period.

The nominal summit of troposphere $\mathrm{CO}$ amount and sensitivity observed from seasonal variations. Record the variation between the seasons with maximum val- ues in the winter and minimum values in the autumn. The seasonal photochemical cycle of hydroxyl radical $(\mathrm{OH})$ in the troposphere cased the seasonal dichotomy of $\mathrm{CO}$ variations. In the Northern Hemisphere, reduction of $\mathrm{OH}$ concentrations coincides with the elevation $\mathrm{CO}$ values concentrations during winter and early spring (McMillan et al., 2003).

From Figure 2, the highest value of $\mathrm{CO}$ raised through the winter and early spring seasons as a results of the increased of partial product by burning of thermal heaters, were used excessively for heating throughout the cold season. In March CO raised to its maximum values throughout the year, though it a bit decreases to medium in April, compare to prior months. Extensive sources are evident in both north and southeast of Iraq with subsequent plumes contributed to $\mathrm{CO}$ concentrations are from Turkey bring by northwesterly wind (winter shamal) driven by the passage of a strong synoptically forced cold front. This variation in the $\mathrm{CO}$ values throughout the period (December-May)

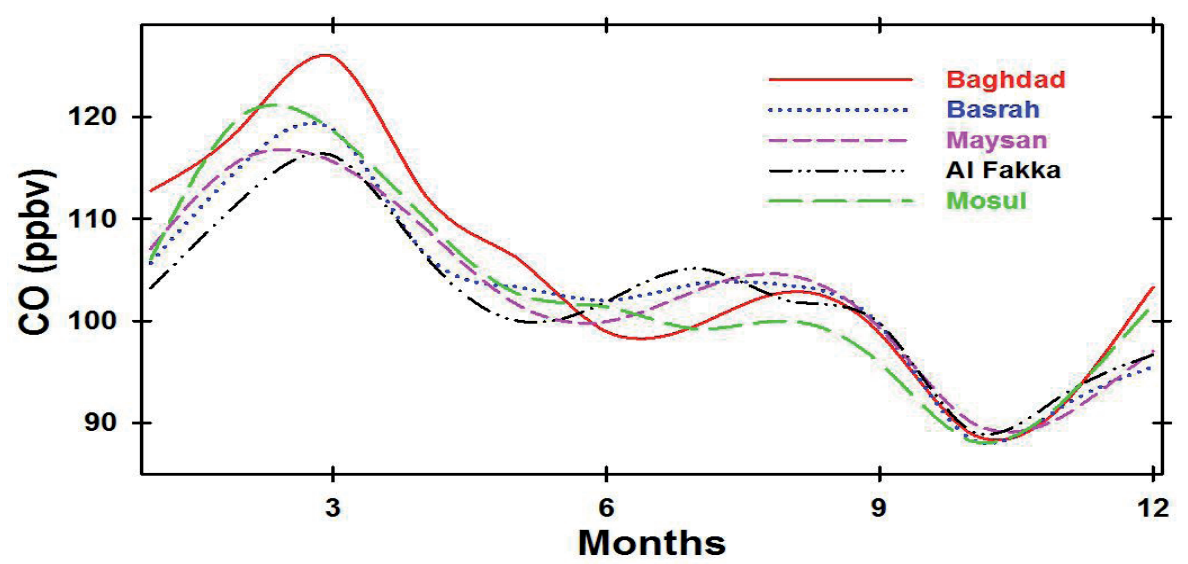

FIGURE 2. Monthly troposphere CO VMR for January to December 2012 for the locations: Baghdad, Basrah, Maysan, Al Fakka, and Mosul 
was also due to the human activity, geographic nature and climatic changes (Salih et al., 2018).

In contrast, during the summer and autumn seasons the troposphere $\mathrm{CO}$ decreases, whereas a bit rise to medium values of $\mathrm{CO}$ in August. The summer season is near the lack of the $\mathrm{CO}$ sources, anthropogenic sources have very small variability, and the $\mathrm{CO}$ emissions from Turkey have very small contribution (Drori et al., 2012). The summer Gasus (shamal) or "wind of 120 days" blows nearly daily through the summer months (June-September) and has great vertical motion over a large natural flat area, which able to diminish the $\mathrm{CO}$ values (Rajab et al., 2013). Elevation of CO concentrations during this period over the southeastern districts compared to its values over the rest areas. All these because of the pollutions released from oil prospecting and extraction, and paddy fields by burning residuals of agricultural (Salih et al., 2018). In this period, the best high value happened on November over Maysan state, and on October was the lowest value.
A slight variation is plainly evident in the comparison between AIRS (dotted line) values of CO with the in situ (solid line) measurements, plotted against months for Baghdad station, as presented in Figure 3. The ground values curve has fluctuations and parallel to the AIRS curve throughout the year. There was a small phase delay between AIRS and ground $\mathrm{CO}$ values. The amplitude of the CO seasonal cycle generally increased to a natural peak in the late autumn season till early spring season between mid-October and March, and there were disparities between the ground and AIRS $\mathrm{CO}$ values resulting from increased its emissions by using fuel heating sources, especially in winter, when temperature and hours of sunshine were at their minimum.

The ground $\mathrm{CO}$ was plotted against the AIRS value, and the results are presented in Figure 4. The agreements between both are fairly good, with a mean deviation not exceeding $4 \%$ between these two sets data. Another indication of the regression was the points tended to cluster along the 45 tangent lines, and

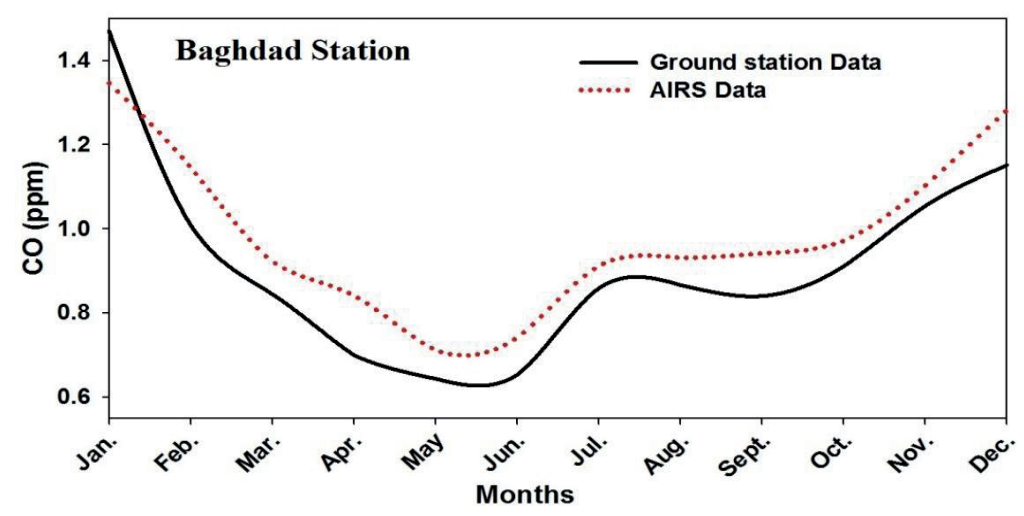

FIGURE 3. The ground station CO (solid line) and AIRS CO values (dotted line) in 2012 for the Baghdad stations 


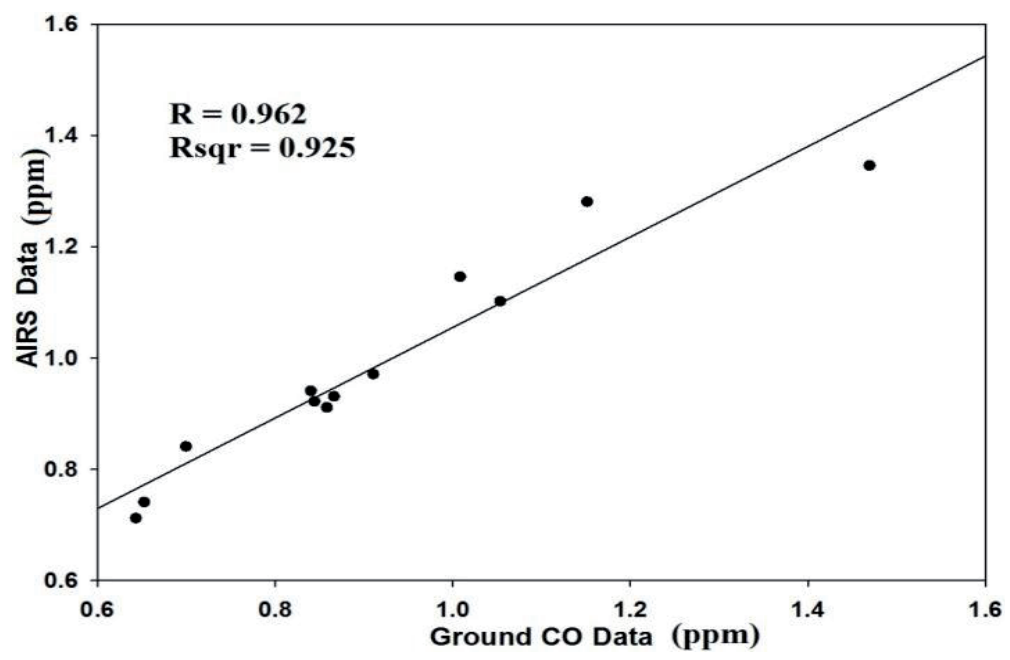

FIGURE 4. The ground station CO versus AIRS CO values for 2012 over Baghdad

yielded the strong correlation coefficient (R) with AIRS for 2012 represented by values 0.962. Observed largest differences between terrestrial and satellite data at January and December due to clouds cover affects to satellite efficiency during winter season (Xiong et al., 2008). In addition, the asset values of $R^{2}$ was 0.925 , and the coefficient of the re- gressions was statistically highly significant $(p<0.001)$. The agreement shows that AIRS is very useful to perform the CO measurements.

An example of $\mathrm{CO}$ values variation with height over study area is illustrated in Figure 5 for 2012 over cross section, Region 49E, 28N, 38E, and 49N. The CO VMR was close to 125 ppbv on De-

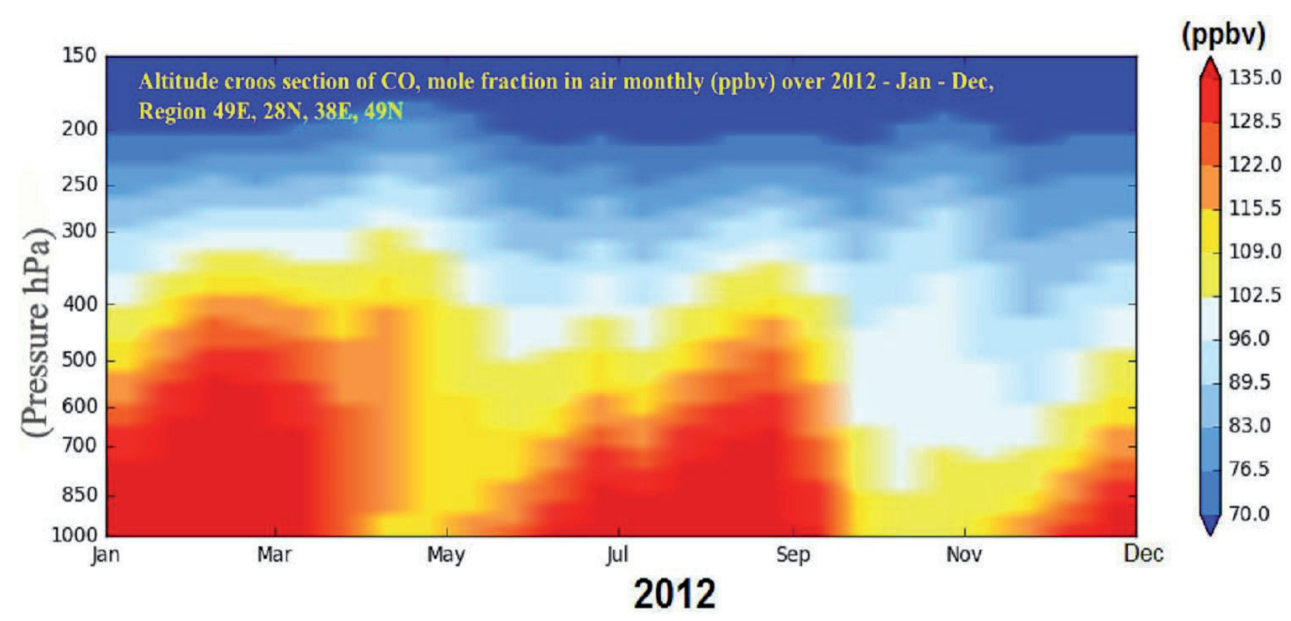

FIGURE 5. Cross section, time-pressure of CO, mole fraction in air ascending monthly over January-December 2012, Region 49E, 28N, 38E, and 49N 
cember-March and July-September at altitude of $850 \mathrm{hPa}$. The magnified $\mathrm{CO}$ values was transported vertically up to $500 \mathrm{hPa}$ on February, and up to $600 \mathrm{hPa}$ during February, March and August. The $\mathrm{CO}$ values were closed to $105 \mathrm{ppbv}$ on February-April at altitude of $350 \mathrm{hPa}$. The lowest $\mathrm{CO}$ values closed to surface was 90 ppbv observed during October at altitude of $800 \mathrm{hPa}$. In addition, Figure 6 displayed a comparison for different levels of mean vertical CO profiles of 12 sets observed by AIRS between 0.75 and $13.5 \mathrm{~km}$ altitude for the locations: Baghdad (solid line), Basrah (dotted line), Maysan (dashed line), Al Fakka (solid-dotted line), and Mosul (long-dashed line) during 2012. All data have been interpolated to a latitudinal grid of $1^{\circ}$. For the clean case (June-November), note how most of the $\mathrm{CO}$ values have similar shapes and peak between 8 and $10 \mathrm{~km}$ altitude and at surface are as significant as any other $\mathrm{CO}$ values, especially in August and September. Near the surface, there are clear inequality and different between the $\mathrm{CO}$ measurements descending from north to south in March, April, May and September, while less difference in other months.

The vertical distribution of $\mathrm{CO}$ shown in Figures 6 is characterized by enhanced abundances of $\mathrm{CO}$, with values that can exceed 120 ppbv at approximately $4 \mathrm{~km}$ altitude over Baghdad and Mosul. This enhanced layer of $\mathrm{CO}$ is present in February, March and April, and begins to dissipate by May. This is due to the moderate and low influence of the northward and eastward winds during this period, which bring favorable CO from Europe, coincides with moderate influence of northward winds over northern Iraq (Drori et al., 2012; Rajab et al., 2013; Faten, 2018). The substantial contribution of anthropogenic from Turkey and Europe carried by eastward wind tag to the local emissions affect the $\mathrm{CO}$ values (Drori et al., 2012), so the troposphere $\mathrm{CO}$ values were have considerable values. The prevailing northeast wind transported favorable $\mathrm{CO}$ plume from the northwest regions of Arab Gulf to the southern Iraq (Badarinath et al., 2010). The lower CO amounts were observed of approximately $88-90 \mathrm{ppbv}$ at $253 \mathrm{mb}$ (altitude $11 \mathrm{~km}$ ) during October. The vertical $\mathrm{CO}$ observation by AIRS is providing meaningful information for different altitude layers closer to the troposphere.

\section{Conclusions}

We present new observations from the AIRS instrument of the vertical distributions of troposphere CO over Iraq. We had started to scrutinize the wealth of CO information for the 2012. The AIRS IR and AMSU (without-HSB) L3 monthly CO retrieval Standard V5 data were used to evaluate and analyses the monthly troposphere $\mathrm{CO}$ spatial and vertical distributions over study area, and quality of the satellite measurements. The $\mathrm{CO}$ concentrations are virtually correlated with weather circumstance and nature of areas geography. The foreseeable variation of monthly $\mathrm{CO}$ was $107.15 \pm 18.75$ ppbv for the entire study duration. The seasonal differences of $\mathrm{CO}$ surface oscillated significantly observed between two seasons, the winter and summer. The lowest $\mathrm{CO}$ measurements observed of approximately $88-90 \mathrm{ppbv}$ at $253 \mathrm{mb}$ 

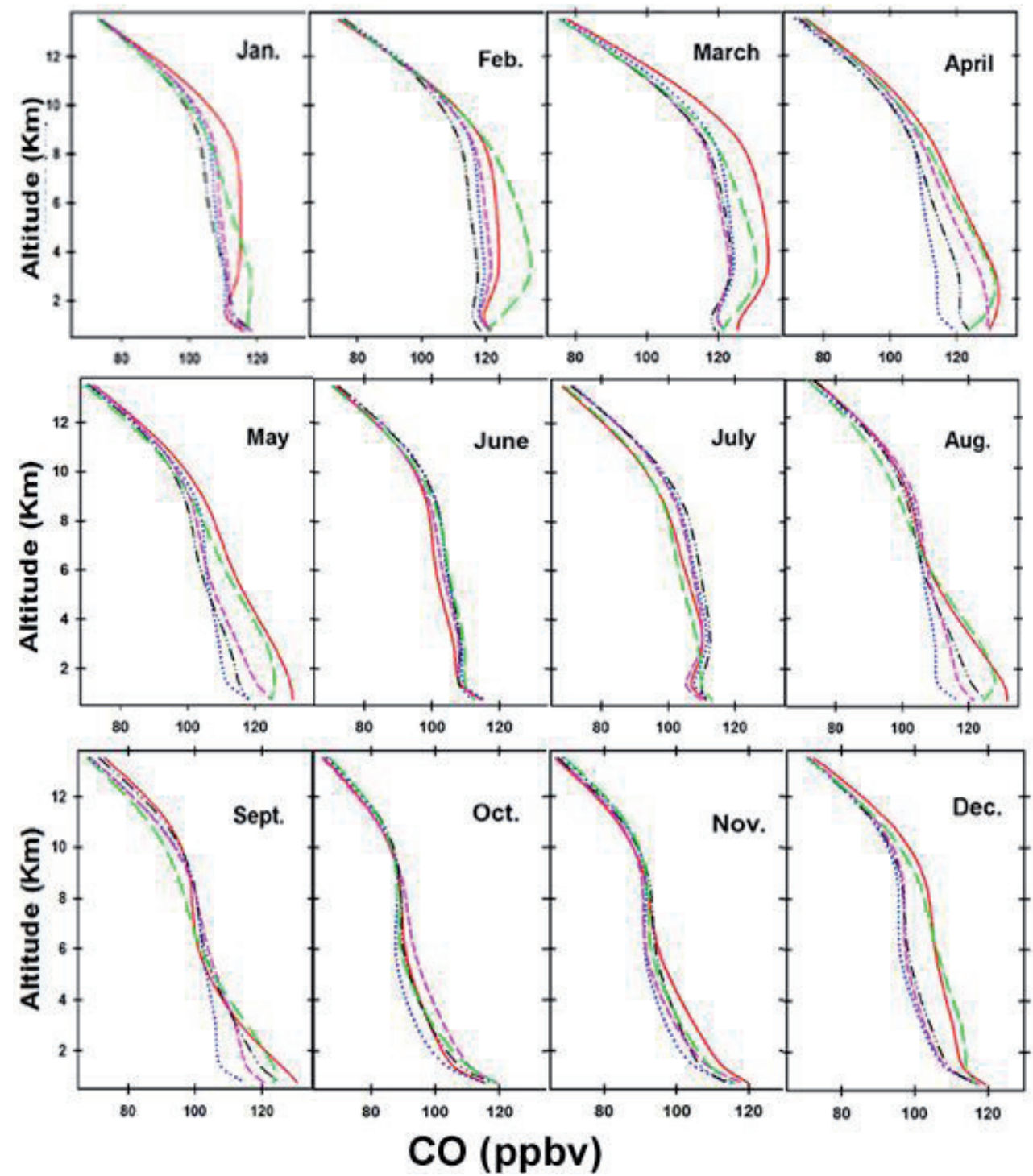

FIGURE 6. Monthly mean January to December 2012 CO vertical profiles over five locations: Baghdad (solid line), Basrah (dotted line), Maysan (dashed line), Al Fakka (solid-dotted line), and Mosul (long-dashed line)

(altitude $11 \mathrm{~km}$ ) during the autumn season, and the highest $\mathrm{CO}$ occurred during spring season on March. Also, the increases in $\mathrm{CO}$ concentrations can be spotted along the year over the manufacturing and crowded urban districts.
The variations in the $\mathrm{CO}$ values from December to May duration were caused by the human actions, geographic regions nature and climatic changes. While the raises of $\mathrm{CO}$ measurements along the June-November duration over 
south-eastern districts compared to its values over the rest areas, was caused by the pollutions released from the oil drilling and extraction, and the paddy fields by burning residuals of crops. Winter shamal bring subsequent plumes from Turkey are contributed to $\mathrm{CO}$ concentrations, and summer shamal have very small contribution to $\mathrm{CO}$ concentrations. Combined ground based and satellite measurements of $\mathrm{CO}$ play a crucial role in obtaining better satellite validate data set. The results show that AIRS are strong candidates in order to improve our knowledge of vertical atmospheric CO. The capability of AIRS information and the satellite observations could enable the researchers in future studies to measure the elevation of the troposphere $\mathrm{CO}$ values over various districts and altitudes, and long periods.

\section{Acknowledgements}

The authors expressed their gratitude to the National Aeronautics and Space Administration (NASA) Goddard Earth Sciences Data Information and Services Centre (DISC) and the NASA-operated GIOVANNI for providing of AIRS data utilized in present research.

\section{References}

Al-Bayati, R.M. \& Al-Salihi, A.M. (2019). Monitoring carbon dioxide from (AIRS) over Iraq during 2003-2016. AIP Conference Proceedings, 2144(1), 030007. DOI 10.1063/1.5123077

Al-Salihi, A.M., Rajab, J.M., \& Salih, Z.Q. (2019). Satellite monitoring for Outgoing Longwave Radiation and Water Vapor during 2003-2016 in Iraq. Journal of Physics:
Conference Series, 1234(1), 012009. DOI 10.1088/1742-6596/1234/1/012009

Badarinath, K., Kharol, S.K., Kaskaoutis, D., Sharma, A.R., Ramaswamy, V. \& Kambezidis, H. (2010). Long-range transport of dust aerosols over the Arabian Sea and Indian region - a case study using satellite data and ground-based measurements. Global and Planetary Change, 72(3), 164-181.

Bowman, K.W., Rodgers, C.D., Kulawik, S.S., Worden, J., Sarkissian, E., Osterman, G., Steck, T., Ming, L., Eldering, A., Shephard, M., Worden, H., Lampel, M., Clough, S., Brown, P., Rinsland, C., Gunson, M. \& Beer, R. (2006). Tropospheric emission spectrometer: Retrieval method and error analysis. IEEE Transactions on Geoscience and Remote Sensing, 44(5), 1297-1307.

Chahine, M.T., Pagano, T.S., Aumann, H.H., Atlas, R., Barnet, C., Blaisdell, J., Chen, L., Divakarla, M., Fetzer E.J., Goldberg, M., Gautier, C., Granger, S., Hannon, S., Irion, F.W., Kakar, R., Kalnay, E., Lambrigtsen, B.H., Lee, S.Y., Marshall, J.L., McMillan, W.W., McMillin, L., Olsen, E.T., Revercomb, H., Rosenkranz, P., Smith, W.L., Staelin, D., Strow, L.L., Susskind, J., Tobin, D., Wolf, D. \& Zhou, L. (2006). AIRS: Improving weather forecasting and providing new data on greenhouse gases. Bulletin of the American Meteorological Society, 87(7), 911-926.

Deeter, M., Edwards, D., Gille, J., Emmons, L., Francis, G., Ho, S.P., Mao, D., Masters, D., Worden, H., Drummond, J.R., Novelli, P.C. (2010). The MOPITT version 4 CO product: Algorithm enhancements, validation, and long-term stability. Journal of Geophysical Research: Atmospheres, 115(D7). DOI 10.1029/2009JD013005

Drori, R., Dayan, U., Edwards, D., Emmons, L., Erlick, C. \& Kanakidou, M. (2012). Attributing and quantifying carbon monoxide sources affecting the Eastern Mediterranean: a combined satellite, modelling, and synoptic analysis study. Atmospheric Chemistry \& Physics, 12(2), 1067-1082.

Faten, G.A., Al-Salihi, A.M. \& Rajab, J.M. (2018). Spatiotemporal Monitoring of Methane Over Iraq During 2003-2015: Retrieved From Atmospheric Infrared Sounder (Airs). ARPN 
Journal of Engeneering and Applied Science, 13(22), 3650-3663.

Fortems-Cheiney, A., Chevallier, F., Pison, I., Bousquet, P., Szopa, S., Deeter, M. \& Clerbaux, C. (2011). Ten years of CO emissions as seen from Measurements of Pollution in the Troposphere (MOPITT). Journal of Geophysical Research: Atmospheres, 116(D5). DOI 10.1029/2010JD014416

Herron-Thorpe, F.L., Mount, G.H., Emmons, L.K., Lamb, B.K., Chung, S.H. \& Vaughan, J.K. (2012). Regional air-quality forecasting for the Pacific Northwest using MOPITT/ /TERRA assimilated carbon monoxide MOZART-4 forecasts as a near real-time boundary condition. Atmospheric Chemistry and Physics, 12(12), 5603-5615.

Illingworth, S.M., Remedios, J.J., Boesch, H., Ho, S.P., Edwards, D., Palmer, P. \& Gonzi, S. (2011). A comparison of OEM CO retrieval from the IASI and MOPITT instruments. Atmospheric Measurement Techniques, 4(5), 775-793.

Kobayashi, H., Shimota, A., Kondo, K., Okumura, E., Kameda, Y., Shimoda, H. \& Ogawa, T. (1999). Development and evaluation of the interferometric monitor for greenhouse gases: a high-throughput Fourier-transform infrared radiometer for nadir Earth observation. Applied Optics, 38(33), 6801-6807.

Landau, S. \& Everitt, B.S. (2004). A handbook of statistical analyses using SPSS. New York: CRC Press Company.

Luo, M., Rinsland, C., Fisher, B., Sachse, G., Diskin, G., Logan, J., Worden, H., Kulawik, S., Osterman, G., Eldering, A., Herman, R. \& Shephard, M. (2007). TES carbon monoxide validation with DACOM aircraft measurements during INTEX-B 2006. Journal of Geophysical Research: Atmospheres, 112(D24). DOI 10.1029/2007JD008803

McMillan, W., McCourt, M., Revercomb, H., Knuteson, R., Christian, T. J., Doddridge, B., Hobbs, P.V., Lukovich, J.V., Novelli, P.C., Piketh, S., Sparling, L., Stein, D., Swap, R.J. \& Yokelson, R.J. (2003). Tropospheric carbon monoxide measurements from the Scanning High-Resolution Interferometer Sounder on 7 September 2000 in southern
Africa during SAFARI 2000. Journal of Geophysical Research: Atmospheres, 108(D13). DOI 10.1029/2002JD002335

NASA Earthdata (2019). Data collections. Retrieved from: http://disc.sci.gsfc.nasa. gov/AIRS

Pétron, G., Granier, C., Khattatov, B., Yudin, V., Lamarque, J.F., Emmons, L., Gille, J. \& Edwards, D.P. (2004). Monthly CO surface sources inventory based on the 2000-2001 MOPITT satellite data. Geophysical Research Letters, 31(21), 1-5.

Rajab, J.M., Jafri, M.M., Lim, H.S. \& Abdullah, K. (2011). Monthly distribution map of carbon monoxide (CO) from AIRS over Peninsular Malaysia, Sabah and Sarawak for the year 2003. Pertanika Journal of Science and Technology, 19, 89-96.

Rajab, J.M., Jafri, M.M., Lim, H.S. \& Abdullah, K. (2012). Regression analysis in modeling of air surface temperature and factors affecting its value in Peninsular Malaysia. Optical Engineering, 51(10), 101702. DOI 10.1117/1. OE.51.10.101702

Rajab, J.M., Ahmed, H.S. \& Moussa, H.A. (2013). Monthly carbone monoxide (CO) distribution based on the 2010 MOPITT satellite data in Iraq. Iraqi Journal of Science, 54(5), 1183-1192.

Rajab, J.M., Hassan, A.S., Kadhum, J.H., Al-Salihi, A.M. \& Hwee, S. (2020). Analysis of tropospheric NO2 over Iraq using OMI satellite measurements. Scientific Review - Engineering and Environmental Sciences, 29(1), 3-16.

Salih, Z.Q., Al-Salihi, A.M. \& Rajab, J.M. (2018). Assessment of troposphere carbon monoxide variability and trend in Iraq using atmospheric infrared sounder during 2003-2016. Journal of Environmental Science and Technology, 11, 39-48.

Xiong, X., Barnet, C., Maddy, E., Sweeney, C., Liu, X., Zhou, L. \& Goldberg, M. (2008). Characterization and validation of methane products from the Atmospheric Infrared Sounder (AIRS). Journal of Geophysical Research: Biogeosciences, 113(G3). DOI 10.1029/2007JG000500 


\section{Summary}

Observed vertical distribution of tropospheric carbon monoxide during 2012 over Iraq. The atmospheric parameters observations enable to made continental and global scales by remote sensing devices existent in space. One of these instruments is the Atmospheric InfraRed Sounder (AIRS) onboard Aqua satellite. We characterize the vertical distribution of troposphere carbon monoxide (CO) measured by AIRS over IRAQ. This study presents one year data. Results shown standard deviation of monthly troposphere $\mathrm{CO}$ for five locations: Baghdad, Basrah, Maysan, Al Fakka, and Mosul, from January to December 2012, was 107.15 $\pm 18.75 \mathrm{ppbv}$ for entire period depend on whether circumstance and topography. The seasonal differences undulate between winter and summer seasons, with higher values $\mathrm{CO}$ in the winter than in the summer and autumn seasons. In addition, the rising in troposphere $\mathrm{CO}$ values can be measured during year over the manufacturing and crowded urbanized zones. AIRS observations reveal enhanced abundances of $\mathrm{CO}$, with values that can exceed $120 \mathrm{ppbv}$ at approximately $4 \mathrm{~km}$ altitude over Baghdad and Mosul. The lower CO amounts observed of approximately $88-90 \mathrm{ppbv}$ at $253 \mathrm{mb}$ (altitude $11 \mathrm{~km}$ ) during October. Comparisons over Baghdad station in 2012 showed close agreement between the ground $\mathrm{CO}$ data and the observed $\mathrm{CO}$ from AIRS, and regression result showed high correlation coefficient $(R=0.962)$. The vertical $\mathrm{CO}$ observation by AIRS is providing meaningful information for different altitude layers closer to the troposphere, and the satellite measurements are able to measure the increase of the atmosphere $\mathrm{CO}$ concentrations over varied regions.

\section{Authors' address:}

Ibtihaj S. Abdulfattah

(https://orcid.org/0000-0001-8543-4112)

Ali M. Al-Salihi - corresponding author (https://orcid.org/0000-0002-6945-767X)

Mustansiriyah University

College of Science

Department of Atmospheric Sciences

Palestine street, 46131, Baghdad, Iraq

e-mail: alialsalihi.atmsc@uomustansiriyah.edu.iq salihi72@yahoo.com

Hwee San Lim

(https://orcid.org/0000-0002-4835-8015) 